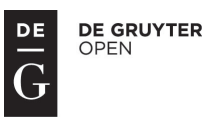

\title{
Public Participation and Democratic legitimacy OF RULEMAKING - A COMPARATIVE ANALYSIS
}

\author{
Iztok Rakar ${ }^{1}$
}

\begin{abstract}
In recent years, public participation has been a frequent object of research, especially in relation to rulemaking procedures. The aim of the paper is to verify a common thesis, that public participation is a means for enhancing democratic legitimacy in rulemaking. In order to do so, the author defines legitimacy and legitimation, presents models of the democratic legitimacy of the executive and compares monistic and pluralistic understanding of democracy. The author then analyzes standpoints of American, English and German legal theory and case law and proposes a possible solution to the main research question.
\end{abstract}

\section{Keywords}

Rulemaking, Public Participation, Legitimacy, Democracy

\section{Introduction}

The rulemaking of the executive represents a deviation from the ideal of the principle of division of powers, the original purpose of which is to prevent tyranny and to secure the freedom, life and property of the individual. ${ }^{2}$ Because the executive possesses its own as well as delegated democratic legitimacy, this (initial) fear of incursions into the (legal) position of the individual would appear at first glance to be minor. But because the rulemaking competence of the executive is constantly expanding and because the role of elections as the first act in an unbroken chain of democratic legitimation (Ger. Legitimationskette $)^{3}$ and as a form of primary participation is diminishing, certain questions ${ }^{4}$ arise, e.g. does the classical model of the democratic legitimacy of the executive suit these changed circumstances, and what role could public participation play in rulemaking processes?

\footnotetext{
${ }^{1}$ University of Ljubljana, Faculty of Administration, Gosarjeva ulica 5, SI-1000 Ljubljana, Slovenia. E-mail: iztok.rakar@fu.uni-lj.si.

${ }^{2}$ Pünder (2009, p. 355).

${ }^{3}$ Köhler (2017).

${ }^{4}$ Ziamou (2001, p. 244).
} 
Public participation is a tool of open and transparent public administration (PA). Openness and transparency are two of the most highlighted principles of contemporary public PA, both at national and supranational (EU) level. In a national context, PA as a part of the executive branch holds the greatest burden of policy- and lawmaking activities. In recent years, convergence of PA reforms has been observed, ${ }^{5}$ as PA face similar problems and various international and other actors promote and spread similar ideas - one of them being public participation in policy- and lawmaking. ${ }^{6}$ Despite different levels of convergence, ${ }^{7}$ we can claim that PA operates in a manner more open to the professional, interested and general public ${ }^{8}$.

What is of special interest is the fact that similar solutions are implemented in states with different legal and administrative cultures and traditions. ${ }^{9}$ While the empirical level of public participation is well covered in the literature, the normative one is less. We therefore aim at providing normative insight into the widespread phenomenon of public participation in PA activities. Our specific aim is to highlight the role of public participation in rulemaking procedures. The primary goal of the paper is therefore to answer the question of whether public participation in rulemaking is a means for enhancing the democratic legitimacy of rulemaking. We use a comparative legal approach to clarify the relationship between the concepts and aim at adding a legal dimension to contemporary research on public administration.

The structure of the paper is as follows: in the second chapter we elaborate the question of functions of public participation; in the third chapter we examine the question of the democratic legitimacy of the rulemaking procedure and in the fourth chapter we elaborate the relationship between public participation and the democratic legitimacy of rulemaking. The final chapter summarizes the findings.

\section{Public participation}

Literature on the subject generally claims that public participation in rulemaking is supposed to enhance the democratic legitimacy of adopted decisions and compensate for deficiencies in the democratic legitimacy conferred by the law, which means that public participation can make it possible to achieve the desired or required level of democratic legitimacy for rulemaking. ${ }^{10}$

At first glance, such a view seems firmly grounded. However, problems arise once one attempts to get to the botton of the term "democratic legitimacy" and the ways in which it can be achieved. Although the terms legitimacy and legitimation can be defined uniformly, the ways in which such a state is to be achieved and such processes are to be carried out

\footnotetext{
${ }^{5}$ Koprić et al. (2014).

${ }^{6}$ E.g. OECD, SIGMA, EU, World Bank.

${ }^{7}$ See Pollitt and Bouckaert (2011).

${ }^{8}$ See, e. g. Johns and Saltane (2016).

${ }^{9}$ We distinguish rule-of-law and public interest legal cultures and several administrative traditions (e.g. AngloAmerican and German) (cf. Kuhlmann and Wollmann, 2014; Painter and Peters, 2010).

${ }^{10}$ For example, Trips (2006, p. 156). For EU, see Ruffert (2014). For a discussion on the argument that procedural standards of (public) participation can be considered part of the rule of law, see Mendes (2014).
} 
vary greatly. Differences exist between individual legal systems which rest on different legal-philopsophical and political-scientific foundations, complicating general overviews. The key problem of such an understanding of the public participation function pertains to the question of who is conferring democratic legitimacy and in what way - is it 1) the people as a whole through general, equal secret-ballot elections, or also 2) the people "in part" and/or individuals through their direct particpation in shaping concrete (authoritative) decisions on all levels of the decision-making process (participation).

In the Rule-of-Law legal culture ${ }^{11}$ the first possible answer to this question applies (the socalled chain of democratic legitimacy). In line with recent understandings of democracy, democraticness is not exhausted by conferring democratic legitimatcy through elections and the legislator, nor is the principle of legality understood as the only benchmark of the functioning of the executive. In line with this understanding, methods of administering, steering and organizing the executive and, in connection with this, the public and the acceptability of the functioning of the latter (so-called output legitimation) appear as additional elements. ${ }^{12}$ Public participation is therefore understood as an expression of democraticness where democracy is understood in a broader sense than that implied by legal science, which treats delegated legislation as a mere source of law and not (also) as a form of action (Ger. Handlungsform). ${ }^{13}$ Democracy means more than just being bound to a law adopted by the legislator; it is also a mode of governance.

The question clearly has a rich legal-philosophical background and touches upon understandings of the state and democracy and adjacent questions of the relations between the state, society and individuals and between general and private interests. ${ }^{14}$ The views of theory on these questions are closely linked to actual socio-political relations and are generally expressed in the different systems of positive law.

\section{The democratic legitimacy of delegated legislation}

\section{Democratic legitimacy and democratic legitimation}

The terms legitimacy and legitimation are central to political, sociological and legal science. On the one hand, this makes it difficult to achieve a uniform definition; on the other, it facilitates the treatment of these terms from multiple angles and enables the transfer of findings between different disciplines and progress in the direction of new demands reflecting the actual circumstances of the functioning of a state.

The point of departure for legal science is the normative concept of legitimacy, which is further "enriched" with empirical elements so as not to be in disharmony with reality. The

\footnotetext{
11 See Kuhlmann and Wollmann (2014).

12 The execution of authority through planned contact and brief commands is said to no longer be acceptable, and in its place the use of ongoing meetings, discussions, clarifications and overviews over extended periods of time is said to have come to the fore. The goal of the process should be to make state decisions transparent, which among other things contributes to resolving complex background issues (Schmidt-Assmann in: Pünder, 1995, p. 259, note 143; Schmidt-Assmann, 2006, p. 101).

13 See Detterbeck (2013, p. 135).

${ }^{14}$ See, e.g. Fisahn (2002).
} 
key point of departure for the normative concept of legitimacy are the demands of the constitution, which is why the actual content of both terms (legitimacy and legitimation) depends on both the constitution and the times. ${ }^{15}$

Here we understand legitimacy as a 1) description of a certain state, as an 2) attribute of authority and as the 3) ultimate product of successfully conducted legitimation processes; legitimation, on the other hand, is understood as those events and processes which must be carried out in order to achieve legitimacy. For the needs of this paper, legitimacy will be understood as the justification of authority. ${ }^{16}$

In line with the majority view of legal theory, authority is justified - that is, legitimate - if it is an expression of the will of the people; in modern states, the will of the people as a holder of authority is for the most part expressed and executed indirectly through bodies of the legislative and judicial branches of power and directly through elections and referendums. ${ }^{17}$ An unbroken chain of democratic legitimation and accountability must exist between the people and bodies of state, as only in this way is it possible to claim that authority is being executed by the people as its source and holder. Theory calls this form of legitimacy ex ante or input legitimacy and distinguishes it from output legitimacy, which implies the acceptability of a decision. ${ }^{18}$ This distinction is very important for public participation in rulemaking.

\section{Models of the legitimacy of the executive}

Theory has designed a number of models of the legitimacy of the executive. ${ }^{19}$ The first model can be called the mechanistic model and focuses on the parliamentary statute (Ger. Gesetz). According to this model, delegated legislation ${ }^{20}$ is supposed to execute the will of the lawmaker (i.e. parliament), and this is thought to be evident in the substance of the parliamentary statute. The substantial legitimacy of delegated legislation is therefore based on the will of the parliament. The executive is understood as an apparatus, as a politically neutral body, and this is already apparent in the frequently used phrase "the programmability" of the functioning of the executive (Ger. Programmierbarkeit). Executive power is supposed to be a transmission belt that shapes delegated legislation on an "objective" legal basis using legal and consequently scientific methodologies. This model produces demands for parliamentary statutes' authorities to be as precise as possible and for the review of delegated legislation from the standpoint of its conformity with

\footnotetext{
${ }^{15}$ Schliesky (2004, p. 729), cf. Teršek (2014).

${ }^{16}$ Such an understanding of the content of legitimacy is a common point of departure for political, sociological and legal science (see Schmidt-Assmann, 2006, p. 87; Schliesky, 2004, p. 729; cf. Trute, 2012, p. 342-343 and Rose-Ackerman et al., 2015).

${ }^{17}$ Representative democracy can be understood as one method for enabling the people to govern themselves democracy would thus be a form of self-government (Loughlin, 2003, p. 47).

${ }^{18}$ See, e.g. Pfeffer (2006, pp. 237 and 239).

${ }^{19}$ Description of models are summarized from von Bogdandy (2000, pp. 443-448). In connection with this, Bugarič (2004, pp. 485) speaks of different theories of administrative law that attempt to find a solution for limitations in the discretion of the executive and the related problem of the democratic deficit.

${ }^{20}$ The term "delegated legislation" (Ger. exekutive Rechtsnormen) is used to facilitate international comparisons. We understand this term to mean legal acts which are issued by the executive and through which legal relations are regulated in an abstract and general manner (cf. Rakar and Tičar, 2014).
} 
parliamentary statute. This model is convincing in cases with very precise parliamentary statutes' authorities, but less so in cases where the executive is given greater regulatory space (Ger. Gestaltungsraum). ${ }^{21}$

The second model is the so-called efficiency model. The main argument of this model is based on the quantity of legal acts that must be adopted in a modern state, which exceeds the capacity of the parliament alone. Delegated legislation is therefore legitimate because it is necessary for the functioning of the modern administrative system ("there's simply no other way"). The shortcoming of this model lies in the fact that it does not answer the question, why are a part of rulemaking activities not privatized? In other words, why does the constitution only foresee politically accountable bodies as the issuers of delegated legislation ${ }^{22}$

The third model is grounded in expertise, and is accordingly called the expert model. At the forefront of this model is the executive's own input in delegated legislation. This model stands in stark contrast to the mechanistic model, as an expert can only input his or her knowledge if adequate space for this input is provided, that is, if he or she is not bound. The parliament can, and, according to certain views, must, leave the regulation of matters linked to specific expertise to the executive. The legimitacy of an expert decision is based on two elements, knowledge and efficiency. An expert decision is therefore legitimate if the experts "know their way around" some thing better than the lay public. ${ }^{23}$ Legal science consequently focuses more on standards for expert decision-making than on the parliamentary statute, which is why a precise explanation of the problem and the rationale of the decision are emphasized. This model has deep legal-philosophical foundations: Hegel, for example, understood the formation of the common good (Ger. Gemeinwohl) as an expert task. ${ }^{24}$ The main shortcoming of this approach is that it is not capable of offsetting the political character of delegated legislation. Its importance is therefore reduced in modern, pluralistic societies, because individuals are not willing to accept rules simply because they were prepared by experts who supposedly "have a firm grasp" on some matter. ${ }^{25}$ The possibility of abuse by experts for political gain also needs to be pointed out. This abuse is said to occur whenever trust in the work of experts increases, and the abuse of this trust means less overall trust in the functioning of public administration. ${ }^{26}$ The fourth model, that of the executive's own democratic legitimacy, is based on the fact that parliamentary elections result, among other things, in the appointment of a chief of the executive. The government therefore has a democratic mandate for political input, part of which it carries out by itself, and part in cooperation with the parliament and other state and societal organizations. The government and the parliament are thought to represent only an internal differentiation of the institutionalized political system, with the latter standing in opposition to public administration in the form of the administrative system.

\footnotetext{
${ }^{21}$ In this case, Bugarič (2004, p. 485) speaks of a formal theory of administrative law.

22 This is not true of English law.

${ }^{23}$ For the discussion on this relationship, see Pečarič (2017).

${ }^{24}$ See Hegel (1821/2005).

${ }^{25}$ Environmental standards and spatial planning can be cited as typical examples.

${ }^{26}$ Bugarič (2004, p. 485).
} 
In this aspect, this model differs greatly from the mechanistic and expert models, as these two models understand the government as "something other than the parliament" - either as a part of the bureaucratic apparatus or as a part of professional groups.

The fifth model of rulemaking legitimacy is based on independent review mechanisms, particularly parliamentary and judicial ones. ${ }^{27}$ With parliamentary review, the key is that parliament, as the body with the highest degree of democratic legitimacy, views the delegated legislation to be politically acceptable. Political review is understood in two ways: as an extension of societal oversight and/or as the oversight of one part of the political system over another part. Underpinning judicial review is the view that the political and administrative systems are strictly separated from the preferences of the individual. At the forefront of legitimation is neither the parliamentary statute nor expertise, but an unbiased procedure that enables an individual to overrule acts due to their disproportionate incursion into his or her interests, which in this case are raised to the level of legal values. The second aspect of this form of legitimation is in the way that the work of authorities is judged by a lay person authorized to make decisions - a judge is not an expert for the regulated field, but a legal expert. ${ }^{28}$

The sixth and final model of the democratic legitimacy of rulemaking bases legitimacy on public participation. The key for this model is the broad, fundamental and fair participation of all those who will be affected by the delegated legislation. ${ }^{29}$ This model is rooted in skepticism regarding the state's ability or willingness to independently design suitable regulation, ${ }^{30}$ which is why it judges the legitimacy of delegated legislation primarily from the standpoint of its creation. At the fore are questions pertaining to the fair participation of those affected, how comments are handled, the adequacy of the time period for participation and the transparency of debates between different, opposing views. ${ }^{31}$ This model also has some obvious shortcomings, as extensive public participation, regardless of its importance for exercising certain fundamental constiutional principles, could lead to the obstruction or even blockage of the rulemaking process. ${ }^{32}$

This overview of models for legitimating the executive shows that some of these models are complementary, while others stand in opposition to one another. This is understandable, as they are based on different assumptions. Societal reality is complex, and the models are designed with the aim of mitigating this complexity. In this sense, it is understandable that combinations of multiple models can be found in positive law, and that this approach is thought to be better able to capture societal reality. By the same token, it would be impossible to design a single, uniform model that would accord with all the

\footnotetext{
${ }^{27}$ For judicial review, see Rose-Ackerman et al. (2015).

${ }^{28}$ Cf. Bugarič (2004, pp. 485-486).

${ }^{29}$ For the connection between more understandable rulemaking materials and broader, better public participation, see Farina et al. (2015). For legal questions pertainin to e-participation, see Tischer (2012).

${ }^{30}$ The state is understood as a highly autonomous societal subsystem, which is why this model questions the predominant understanding of the state and legitimacy and forms a contrast to the expert model.

${ }^{31}$ Pfeffer (2006, p. 237).

${ }^{32}$ For the desirability of future developments in public decision-making from the viewpoint of policy-makers, see Wagner et al. (2016).
} 
premises presented above. ${ }^{33}$ We now turn our attention to the presentation of legal theory on delegated legislation's democratic legitimacy.

\section{Legal theory}

By way of comparison, three fundamental approaches to the democratic legitimation of delegated legislation can be outlined: ${ }^{34}$

1. Through the parliamentary statute;

2. Through participation from the parliament;

3. Through direct public participation.

In the first two cases, the holder of legitimation is the parliament, in both an ex ante (parliament statute's authorization to issue delegated legislation) and ex post (participation in the process for issuing delegated legislation) sense.

In the US, emphasis is on public participation due to the limited ability of the parliament (Congress) to participate in the rulemaking process ${ }^{35}$ and to the flexible approach of the US Supreme Court in the matter of the substantial precision of laws. ${ }^{36}$ In line with the view of the US Supreme Court, public participation serves to compensate for the so-called substantial imprecision of the parliamentary statute. Accordingly, the efficient and fair participation of the public is thought to ensure the democratic legitimacy of the adopted delegated legislation. ${ }^{37}$

In the view of legal theory in the US, the democratic legitimation of delegated legislation is similar to that of parliament's statute if the public can exert its influence on its formation in the same way as it attempts to influence holders of legislative powers. For the most part, this implies the transparency of the procedure and equal opportunity for all who participate ${ }^{38}$ which is supposed to prevent the overly powerful influence of large interest groups (agency capture). ${ }^{39}$

The detailed legal regulation of the rulemaking procedure and stringent review by the courts are thus understood as a substitute for the classical democratic decision-making process, in which representatives of the people are elected and politically accountable

\footnotetext{
33 In a similar sense Harlow (1999, p. 265).

${ }^{34}$ Pünder (2009); cf. Ziamou (2001, pp. 26-40).

35 The US Supreme Court considers an executive veto on issued delegated legislation to be unconstitutional (see Immigration and Naturalization Service v. Chadha (1983) 462 US 919).

36 Pünder (2009, p. 369).

${ }^{37}$ As far as costs of public participation are concerned, according to Woods (2015) requirements to provide public notice of agency environmental rulemaking do not have a significant effect on the regulatory compliance costs imposed on industry, but mechanisms that provide direct access to rulemaking processes serve to decrease these costs. Cf. Rose-Ackerman et al. (2015).

38 This is one of the central contents of a fair procedure - see Dworkin (1986).

${ }^{39}$ This line of thought is based on a model of representing interests which partially finds support in the theory of public choice. In this regard, the rulemaking process must be structured like the legislative process. The problem is therefore not the breadth of powers granted to the executive, but the way in which these powers are executed. Cf. Freeman (1997), who recommends a collaborative governance model.
} 
to voters. The backdrop for this thinking is of course the abovementioned understanding of democracy and public administration, in accordance with which the policy-making process does not end, but in fact begins, with the adoption of a parliament's statute. ${ }^{40}$

Placing the above in a general theoretical framework, the foundation for the legitimacy of delegated legislation within a model of interest representation based on a pluralistic understanding of democracy is the broad opportunity for the participation of a public possessed of equal opportunities to impact the shaping of decisions, with such opportunities guaranteed by rigorous oversight by the courts. ${ }^{41}$

Although case law and legislation are familiar with numerous cases and forms of public participation in the activities of the executive, in (Continental) European theory the emphasis is on the potential for democratic legitimation. In German theory, for example, one does not find broad-based discussions of public participation as an instrument of the democratic legitimation of delegated legislation. ${ }^{42}$ In line with the majority view of German theory and constitutional court case law, public participation primarily serves to transmit information ${ }^{43}$ and expert knowledge and to ease the enforcement of rules in practice, and not to instill delegated legislation with democratic legitimacy. ${ }^{44}$ The entire burden of democratic legitimation is therefore borne by the parliament: in terms of substance through adequately precise and narrow authorizations, and in terms of process through the enforcement of the responsibility of the government for the work of the executive and through participation in the rulemaking process. ${ }^{45}$ The German constitutional system is thus based on the substantial ex ante legitimation of the executive (statutory authority), which is why procedural ex post legitimation ${ }^{46}$ (participation of the parliament in issuing delegated legislation) is only rarely used. ${ }^{47}$ These approaches to the democratic legitimation of the executive are the response of German theory and the German Constitution to the problem of the executive's democratic legitimacy deficit, which is why public participation is not understood as a general demand of constitutional law intended to compensate for this deficit. $^{48}$

In German theory, public participation that exceeds general and equal elections is looked on with skepticisim, as the public is thought to follow particular interests and not some

\footnotetext{
${ }^{40}$ Pünder (2009, pp. 370-371); cf. Rose-Ackerman et al. (2015).

${ }^{41}$ For EU, see Türk (2013).

${ }^{42}$ Vagt (2006, p. 223, note 503). Some examples of discussions: Pünder (1995, p. 258); Schmidt-Assmann (1982, p. 46); Schmitt-Glaeser (1984, p. 48); von Bogdandy (2000, pp. 443-448).

${ }^{43}$ According to Brintnall (2011), models for regulatory participation have confused participation with information.

${ }^{44}$ Rose-Ackerman et al. (2015, p. 162-163).

${ }^{45}$ Von Bogdandy (2001, p. 368).

${ }^{46}$ That is, the participation of the Bundestag; due to its composition, the Bundesrat has a democratic legitimacy deficit. The purpose of its participation in issuing laws is therefore different - it ensures the adequacy of a decision, in line with how, as a federal body, it represents the perspective of the state as a whole (for a detailed discussion, see Vagt, 2006, pp. 119-120, 222 and 226).

${ }^{47}$ Vagt (2006, pp. 217-218).

${ }^{48}$ Möstl (2006, p. 562). Cf. Virant (2009, p. 6). The same stands for the EU context (see Ehlers and Erichsen, 2010, p. 232).
} 
general (public) interest. ${ }^{49}$ The democratic legitimacy of the executive therefore has its basis in the personal legitimacy of general and equal parliamentary elections, as only here is it possible to ensure strict, formal political equality, that is, equal opportunity for all citizens to influence decision-making. ${ }^{50}$ Consequently, only those German theorists who have a pluralistic understanding of democracy tend to view public participation favorably. ${ }^{51}$ In English literature, the question of direct public participation in rulemaking procedures is rarely dealt with, as legitimation takes place indirectly, through elected representatives of the people. ${ }^{52}$ As in Germany, the democratic legitimation of delegated legislation is supposed to be provided for by a parliamentary statute which creates a basis for issuing delegated legislation and by the participation of parliament. ${ }^{53}$ A part of English theory therefore finds that public participation in rulemaking, as one possible form of political participation (so-called secondary participation), ${ }^{54}$ is a "no man's land." ${ }^{55}$ The law safeguards both poles of this process, elections and participation in the administrative procedure in the narrow sense (adjudication), while the intermediate space is deemed less important. 56

In English theory, public participation as a form of the democratic legitimation of delegated legislation can therefore be seen to have support for the most part from proponents of a pluralistic understanding of democracy. ${ }^{57}$ The deficit of legal legitimacy inherent to delegated legislation is said to be levelled by public participation, specifically by the participation of those groups to whom the rules apply. The democratic legitimacy of

\footnotetext{
${ }^{49}$ This line of thought is based on a strict division between the spheres of state and society, which benefits not only individuals (the protection of rights), but also the state (protection from particular interests). There exists a principled opposition between general and particular interests: the general interest is mystified and associated with a "higher" goal, which is why the state, being subject to a similar mystification, has the exclusive right to decide on the general good (general interest). For a concise treatment of the development of the German theory of the state, see Fisahn (2002).

${ }^{50}$ Ziamou (2001, p. 245), von Bogdandy (2001, pp. 368-369). For expectations about the future of public participation in Germany, see Vogt and Haas (2015).

${ }^{51}$ E.g. Petersen (2010).

${ }^{52}$ For example, when addressing the question of public participation as an approach to the democratic legitimacy of delegated legislation in Great Britain, one of the most important German theorists who works with comparisons of delegated legislation law in the US, Germany and Great Britain only lists legal systems and the views of case law; he does not touch upon the question of theoretical bases and backdrops (see Pünder, 2009, pp. 372-374).

${ }^{53}$ Unlike in the German constitutional system, the main role is played by the ex post participation of parliament (so-called affirmative procedure), as the English parliament is not as limited as its German counterpart when delegating rulemaking competencies (see Article 80 of the Grundgesetz - Ger. Bestimmtheitstrias) (Pünder, 2009, p. 378; Vagt, 2006, p. 219).

${ }^{54}$ Ziamou (2001, p. 245).

${ }^{55}$ Craig (1990, p. 173). This view therefore derives from the same understanding of democracy as in the US, specifically that the political and legal process do not conclude, but, in many cases, actually begin with the adoption of a law (see Pünder, 2009, p. 374).

${ }^{56}$ Craig (1990, p. 173) feels that this is not sound, and lists three main arguments: 1) The provision of legal protection to only two forms of participation is based on an inadequate, simplified theory, 2) the difficulty of delineating legislative activities and adjudication and 3) a possible analogy between the reasons listed in support of participation in adjudication in the narrow sense and reasons from other contexts of the functioning of the state. See Rakar (2014). For development of administrative procedures in Eastern Europe, see Sever et al. (2014). ${ }^{57}$ Ziamou (2001, p. 245). Older pluralists include Laski, Cole and Barker, while newer names include Gamble, Nozick and Jordan.
} 
delegated legislation is thought to be greater because subjects affected by the legislation can influence the content of the rules. ${ }^{58}$

The following conclusions can be extracted from this comparative overview:

1) A common feature of all analyzed legal orders is the democratic legitimation of delegated legislation by means of the parliamentary statute (ex ante legitimation by the parliament).

2) In Great Britain and Germany, delegated legislation is also legitimated by the participation of the parliament in the process of issuing delegated legislation (ex post legitimation by the parliament).

3) In the US, the main form of democratic legitimation of delegated legislation is the rulemaking process and public participation in the framework thereof.

4) There exists a close link between an understanding of public participation as a form of the democratic legitimation of delegated legislation and a pluralistic understanding of democracy.

\section{Public participation as a means of democratic legitimation of rulemaking}

\section{German vs. US model of democratic legitimation}

For the needs of this paper, we will draw a distinction between the two dominant models of democratic legitimation: the US model based on public participation and the German model based on the parliamentary statute.

Viewed from the perspective of the principle of democracy, in our view the key question presented by public participation in rulemaking pertains to an understanding of democracy. The substance of the term "democracy" cannot be captured in just one sentence, nor, of course, can the different types of democracy. For the needs of this paper, a distinction will be drawn between a pluralistic understanding of democracy, such as predominates in the US tradition, and a monistic understanding of democracy, such as predominates in German theory.

The point of departure for a pluralistic understanding of democracy is the individual; in a monistic interpretation, it is the people.$^{59}$ These starting points are of decisive importance in addressing the question of the democratic legitimacy of public participation in rulemaking.

In the 1970s, the so-called classical model of the democratic legitimacy of the executive took shape in German theory. This model contains the following components:

1) the people (the subject of legitimation);

2) the authority of the state (the object of legitimation);

3) methods of legitimation (acceptable instruments for establishing a connection or imputability between subject and object);

\footnotetext{
58 Vagt (2006, pp. 222-223).

${ }^{59}$ See Bryde (1994).
} 
4) the degree of legitimation (ensures both the mutual functioning of the methods of legitimation as well as the effectiveness of the connection). ${ }^{60}$

In this part of the paper, the following assumptions of the individual components of this model are key: the people, and not the individual, are a point of departure, whereby the people is more than just a collection of individuals; it is a uniform, spatially and substantially undefined general "body", and these features make it the only entity capable of transmitting democratic legitimacy to the parliament through general and equal elections. The object of legitimation is authority, by which is meant the end product of a complex process of forming opinions, wills and decisions, to the near total exclusion of the substance and formation of the decision. ${ }^{61}$

The classical model of the democratic legitimacy of the functioning of the executive recognizes a numerus clausus of legitimation methods: 1) institutional-functional, 2) organizational-personal and 3) material-substantial. For this paper, the unbroken chain of legitimation running from the people to the individual official executing authority and back (personal legitimation) is key, as is the substantial linkage between state authority and the people, which has two mutually non-interchangeable bases: the bond between the executive and the parliamentary statute and the accountability of the government to the parliament (substantial legitimation). It goes without saying that the key role in this form of legitimation is held by the parliamentary statute. This is the case regardless of the statute's limited ability to specify the functioning of the executive (Ger. Steuerungsdefizit des Gesetzes).

All these methods of democratic legitimation are devoid of meaning in and of themselves, and achieve significance only at the point at which they intertwine. From the standpoint of constitutional law, it is not the method (form) of legitimation that is important, but the effectiveness of legitimation, which stems from the joint action of all these methods and manifests itself in the form of a particular degree of democratic legitimacy. ${ }^{62}$ To achieve the desired degree, an individual form of legitimation must not be replaced with another, although the forms can balance each other out to a certain extent, in line with the different methods of action of individual forms of legitimation. ${ }^{63}$

These points of departure clearly show that every form of public participation that goes beyond elections (as that instance which provides strictly formal political equality as a cornerstone of democracy) is viewed with caution. On the one hand, public participation could pose a threat to the public interest due to the predominance of special and partial interests, and on the other it breaks the chain of legitimation that runs from the people and back.

\footnotetext{
60 Trute (2012, pp. 346-353).

61 The currently prevalent view is that all functioning which could be attributed to state bodies must be legitimate (there are therefore no trifling reservations - Ger. Bagatelvorbehalt) (Trute, 2012, p. 347).

62 BVerfGE 93, 37.

${ }^{63}$ Schmidt-Assmann (2006, p. 99); similarly Trute (2012, pp. 383-384). The concept of an adequate degree of legitimacy lends flexibility to the monistic concept of legitimacy, as it enables, on the one hand, existing forms of legitimacy to compensate or strengthen one another and, on the other, it opens the door for new forms of legitimacy (organizational and procedural forms, for example) (Schliesky, 2004, p. 289 and 302).
} 
Since its conception, the classical model of legitimation has also been met with criticism aimed at both its assumptions regarding the theory of the state and its normative and empirical aspects. ${ }^{64}$ Critiques citing the theory of the state are more important for this paper, as distrust towards partial interests has already been mentioned several times. A developmental overview of German theory of the state shows that a turn towards the general good (Ger. Allgemeinwohl) occurred in the Imperial period. The general good or public interest appears at first as an abstract notion apart from special interests and reveals itself to be above these interests. Together with unity and homogeneity, public interest was a key mystification that served the authoritarian design of a community existing alongside the original organization of interests. ${ }^{65}$ The integration of society is therefore not the result of a balancing of different and contrasting life situations, interests and cultural backgrounds, but is instead enacted in an authoritarian fashion and mystified as a community sharing the same destiny. Contradictions within society dissipate beneath the authoritarian definition of the general good, which is capable of separating and emancipating itself from special interests with significant consequences. In line with positivism, the state is not understood as an organism (any longer), but as a merging of wills that possesses or forms a uniform will. State decisions are therefore not the decisions of majorities or officials at institutions, but rather an expression of the general will of a people understood uniformly by the statute. This will is emancipated from the actual will and interests of the people. In a legally regulated state decision-making processes, one not only speaks of the "statute" and the general will, but also - and at the same time - of a unified people that takes shape through these processes. The general will and general good are divorced from individuals and subsumed in the state and its bodies.

The uniformity of the people achieved through the state has important consequences for understanding public participation. Individual or specific group interests are placed in opposition to the general interest, which the state defines as a matter of unity. The state or its bodies act as bulwarks of the public interest against the egoistic interests of individuals or associations thereof. In accordance with this interpretation, the interests of civil society are only important if they serve to inform the state of guaranteed rights that could also exist alongside generality or if they provide the state with the expertise it requires to define the general interest - the function of public participation is therefore to inform the state. ${ }^{66}$ Such an understanding rests on a stark delineation of the state and society and attributes the general good, along with competencies for its definition and enforcement, exclusively to the sphere of the state. The 1970s saw the return of intensive debates on the role of public participation in the work of the executive. One of the most influential concepts to take shape within legal science was the concept of hierarchical democracy, in line with which democracy's key feature is the legitimacy of even the lowest official as provided

\footnotetext{
${ }^{64}$ Although criticism aimed at the classical model is multifarious, the reasons for it can be sought for the most part in a different understanding of the substance of democracy and changes in the theory of the state that occurred in response to European integration and internationalization (see Trute, 2012, p. 353).

${ }^{65}$ Under feudalism, the community was made up of classes, guilds and other orders that were assigned public tasks and functions; under liberalism, the community was based on a leveling of personal interests accomplished through the rational discussions of autonomous individuals (Fisahn, 2002, pp. 74-75).

${ }^{66}$ Fisahn (2002, pp. 55, 74-75, 85 and 230).
} 
through general elections as an act of legitimation, one feature of democracy being the legitimation of state authority through general elections. ${ }^{67}$ As presented above, under the classical (monistic, hierarchical) model of democracy and the classical model of lawmaking, the entire burden of the democratic legitimation of delegated legislation is "heaped upon" the parliament, which performs this function both on the substantial level and the procedural level - in the case of the former through suitable substance of statute's authorizations for issuing delegated legislation, and in the case of the latter by enforcing the responsibility of the government for its work and by participating in the rulemaking process. In line with this understanding of democracy, augmentation of the democraticness and therefore the legimitimacy of decisions can only be achieved by improving the election system, tightening the bond between the executive and the parliamentary statute or with a referendum. 68

The classical model of the legitimacy of the executive, which is based on guidance provided by the law, hierarchy and personal legitimation, is very clear and harmonious; at the same time, it is overly simple ${ }^{69}$ and underestimates the complexity of making and enacting legal norms, a complexity that appears in a number of fields of administrative law.

According to pluralistic understandings of democracy, the point of departure for democracy and legitimation is the individual and his or her dignity. Pluralism starts from the self-authority of free and equal individuals, and thus from the principle of individual freedom of self-determination (Ger. Selbstbestimmung) ${ }^{70}$ On the basis of his or her dignity and the guarantee of free decision-making stemming from it, the individual can justify (legitimate) authority exercised over him. An understanding of democracy that places individual or human rights at the center is dynamic, as it understands democracy as a demand for optimization, unlike the staticity inherent in the monistic concept. ${ }^{71}$ Besides personally conferred legitimacy, a pluralistic understanding of democracy also demands a legally designed process for decision-making by authorities in which individuals participate or at least input values, initiatives and demands. ${ }^{72}$ Provided that certain conditions are met, other forms of participation - not just elections - can therefore be counted as forms of the realization of democracy. ${ }^{73}$

To return to the basic understandings of democracy used in this paper (monistic and pluralistic) and derive from them models for legitimating authority, it may be concluded that a large gap exists between the two understandings, which is why one must exercise caution when stressing the democratic function of public participation in rulemaking and

\footnotetext{
67 The most important advocate of this concept of the state and democracy is Böckenförde.

68 Von Bogdandy (2001, pp. 369-370).

69 Theory describes it with the term "administrative optimism", as the executive power is thought to be the executive instrument for acts of the will of parliament and in this regard to act in the spirit of representing the people (Trute 2012, p. 365).

70 Trute (2012, p. 356).

71 The first approach is based on an understanding of democracy as a principle, and the second is based on an understanding of democracy as a rule from which concrete decisions can be derived on the basis of subsumption (for a detailed discussion, see Trute, 2012, pp. 354-355).

${ }^{72}$ It is not essential that they have the formal opportunity for (joint) decision-making, but only that they present their suggestions and expectations and that these are weighed in a rationally designed process.

73 Von Bogdandy (2001, p. 376).
} 
steer clear of generalized statements reflecting solutions presented by legal systems based on different concepts and models. ${ }^{74}$

All this leads to the question of whether it would be possible to identify points of commonality between the two models and, by doing so, to attribute a democratic function to public participation in rulemaking even in those legal systems that are based on a classical model of democratic legitimation.

\section{Towards a common solution?}

Newer German theory and constitutional court case law have created an inroad to an understanding of the individual and his or her dignity as foundations of democracy, but this has been limited to the field of deciding on one's own affairs, specifically on local and so-called functional self-government (Ger. Funktionale Selbstverwaltung), and largely overlooks less intensive forms of participation. ${ }^{75}$ In accordance with the majority view of theory, the essence of democracy is thought to be the opportunity to decide, and not just to consult (for example). ${ }^{76}$

In opposition to this stands an understanding of the democratic community as a community open to valuations and initiatives from individuals, which is why every (sic!) opportunity for inputting the views of individuals in state decision-making processes has a democratic function. What is essential is that these initiatives be treated (seriously) and that the individual is in this way offered a concrete possibility for jointly shaping a decision. ${ }^{77}$ Democracy is therefore not exhaused with elections and the feedback loop between authority of the state and the people, or, in other words, the criteria for the democraticness of a system are not derived directly from constitutional provisions, but also from the unwritten, essential features of such a system (so-called pre-legal assumptions). ${ }^{78}$

At this point, reference can be made to the concept of participatory democracy, in accordance with which democracy is understood as a political system in which citizens elect their representatives at elections, but where they also remain active co-participants in the process of political decision-making on all levels of adopting a decision. ${ }^{79}$

What is essential is that democracy takes different forms as it appears in reality, and that these forms are more diverse than the sum of theoretical concepts of legal and political science, and, lastly, that the fundamental principles of democracy - despite their firm

\footnotetext{
${ }^{74}$ It is otherwise with public participation from the standpoint of the principle of effective administration, which refers to formulating bases for decisions (obtaining information and expert knowledge) and the possibility of enforcing rules in practice (acceptability, output legitimacy). Yet caution is again in order in the case of public participation as a form of legal protection: in American theory, for example, the public can act as a defender of the public interest, whereas this is not possible in German and (generally) in Slovenian theory. See Rakar (2014).

${ }^{75}$ See, for example, Trute (2012, pp. 361-362).

${ }^{76}$ For example, Schmidt-Assmann (1991, p. 374). Cf. Avbelj (2011, p. 730).

${ }^{77}$ See, for example, von Bogdandy (2000, p. 85); see also von Bogdandy (2001, pp. 380-381).

${ }^{78}$ Bröhmer (2004, p. 16) and BVerfGE 89, 155 (185). Similarly, Teršek (2009, p. 9), who speaks of "elements beneath the surface of the democratic form" and the "substantial, even material postulates of democracy".

${ }^{79}$ Teršek (2009, p. 11). Dialog or discursive democracy is another form of democracy in which the process of adopting a decision is based on an interactive relationship between members of society, that is, on their mutual, rationally founded suasion (ibid.). For the Italian case, see Fraenkel-Haeberle (2013) and Mattarella (2010).
} 
foundations - adapt to suit time and space. ${ }^{80}$ This must be kept in mind when judging the democratic dimension of public participation in rulemaking. One approach that opens the possibility for transferring ideas between the two understandings of democracy in the field of rulemaking is the distinction between the classificatory and comparative dimensions of the term democracy. ${ }^{81}$

In line with the former dimension, a system can be democratic or non-democratic - there are no other options or gradients in this category. In line with the latter dimension, a system that, in accordance with the above, is democratic, can be more or less democratic.

The first dimension of democracy is static and can be linked with an understanding that views democracy as a rule from which concrete solutions may be derived on the basis of subsumption, while the second dimesion is dynamic and can be associated with an understanding that views democracy as a principle that supports development and optimization. ${ }^{82}$ Concrete constitutional rules that determine the content of the term democracy should therefore represent only a partial definition and concretization of this constitutional principle, which consequently means that other forms of realizing democracy may be added to the main form of realizing democracy (elections that confer personal democratic legitimacy). ${ }^{83}$

The problem of the comparative dimension of democracy lies in the fact that the guidelines that are supposed to indicate the different degrees of democracy are themselves subject to debate, while the standards for defining democracy in the classificatory sense are very clear. The question is therefore whether public participation in rulemaking represents one such guideline.

To relate the different starting points of democracy (the people and the individual) to the different dimensions of the term democracy (the classificatory and the comparative), taking account of the fact that the executive is persistently gaining space for its own design and that elections in modern states are losing their significance as the key (or even exclusive) transmitter of societal preferences, the following can be stated: if a system meets the demands for being classified as democratic, it can be more democratic if it has in place processes through which the public is enabled to participate in rulemaking, on the condition that these processes do not, at the same time, pose a threat to the validity of the key suppositions of democracy and the axioms of the state. ${ }^{84}$

In line with this understanding of democracy, public participation offers potential for the democratic legitimation of delegated legislation, but caution is in order in systems based on a monistic understanding of democracy, particularly with regard to preserving the state's decision-making autonomy - in these systems, forms of decision-making that provide supporters of particular interests with veto or even decision-making powers are unconstitutional. ${ }^{85}$ The public interest is in fact established as a synthesis of particular

\footnotetext{
80 See Teršek (2009, p. 10).

81 Thus von Bogdandy (2001, p. 367).

${ }^{82}$ See Trute (2012, pp. 354-355) and von Bogdandy (2001, p. 368); cf. Meny and Knapp (1998).

83 Von Bogdandy (2001, p. 369); cf. Teršek (2009, pp. 9-11).

${ }^{84}$ Thus von Bogdandy (2001, pp. 373, 376, 380 and 384).

85 Such a form of participation is thought to be an anachronism from the age of corporatism, and not a possible
} 
interests, but considerable distance from the latter is a constitutional demand..$^{86}$ Therefore, although public participation is important, its limits are also important. ${ }^{87}$

One of the key problems of this understanding of democracy is the question of political equality. One solution to this problem reads as follows: political equality is in fact a fundamental form for exercising democracy, but it is not the only form, as the substance of democracy is built upon by respect for human dignity and the autonomy of the individual. Democracy is therefore a political system which, besides political equality, offers the greatest possible opportunity for affected subjects to input their preferences. It logically follows that there must exist other procedures for cooperation besides elections. ${ }^{88}$

Public participation in rulemaking is thought to enhance the acceptability of the rules, which theory treats as the ex post legitimacy of adopted decisions. One of the basic hypotheses of a sociological treatment of processes states that those who participate in a process will be more likely to accept a decision as justified if they consider the underlying process to be fair, whereby the normative criteria of a fair process include, for example, the possibility of issuing statments, providing explanations of a decision and the impartiality of the decision maker. ${ }^{89}$

This hypothesis pertains for the most part to the judicial process, which is why theory does not have a uniform view of whether it also pertains to administrative systems. On the one hand, for known German theorists in the field of administrative law and administrative science, the acceptability of the decision is problematic as a goal of administrative procedure law, as the decision is supposed to be very precisely "programmed", in the legalistic sense, in the administrative procedure. On the other hand, the sociologically oriented research of administrative law found in US theory places great emphasis on the acceptability of the decision, and in doing so echoes a part of German theory. The latter understands procedural rights to participate in the process as an ideal means for participation in the execution of authority, ${ }^{90}$ for the mutual process of distributing information and communication between the individual and the state and for the self-validation and development of the individual. Procedural guarantees are thought to enable a democratic understanding of participation in the administrative process. ${ }^{91}$

This aspect is stressed particularly in those fields of functioning of the executive where the law does not provide an adequately precise substantial framework, for example in the field of delegated legislation. Public participation in these processes is therefore said to contribute to a decision's acceptability on the grounds that the decision is democratically

future form of participation (von Bogdandy, 2000, p. 85).

${ }^{86}$ Besides determining forms for decision-making and obtaining and disseminating information, ensuring distance be kept is one of the key tasks of organization as a new form of the democratic legitimation of the executive (see Trute, 2012, pp. 372-373).

${ }^{87}$ Von Bogdandy (2000, pp. 80-87).

${ }^{88}$ Von Bogdandy (2001, p. 376).

${ }^{89}$ See, for example, Luhmann (2001).

${ }^{90}$ Similarly, Jerovšek and Trpin (2004, p. 86), who links the principle of hearing a client in adjudication to the principle of democracy, as the will of the people is thought to substantially determine and oversee every form of the execution of authority.

${ }^{91}$ More on participation in Kovač and Sever (2014, pp. 144-160). 
legitimate due to its direct, two-way linkage to the people. This legitimacy is not originary or ex ante legitimacy, but ex post legitimacy, that is, it pertains to the acceptability of the decision. In the opposite case, the chain of legitimation which starts with elections would be broken. ${ }^{92}$

\section{Conclusion}

The following conclusions can be drawn from the overview presented above: 1) with public participation in rulemaking, the ex ante and expost legitimization functions must be distinguished; 2) the ex post legitimation function stems from a sociological examination of legal processes and pertains to the acceptability of the adopted decision, which is supposed to ease the enforcement of the latter in practice; 3 ) the ex ante legitimation function can be discerned in pluralistic and participatory undertstandings of democracy; 4) the ex ante legitimation function is not found in the monistic (hierarchical, vertical) model, because it would break the chain of legitimacy that starts with elections - decisions which only a part of the public could influence, in line with its partial interests, can no longer be linked to the people as a whole, and the people are the ultimate holder and executor of authority; 5) placing emphasis on the ex ante legitimation function as a generally valid function is too simplistic, as in doing so one fails to take into account the different legal-philosophical bases of the two models of democracy and 6) elements of the pluralistic model may be inputted in the monistic model, provided certain conditions have been met: a) the key role in legitimation is still attributed to the law (that is, to the people and, through elections, to the legislative body); b) the point of departure for democracy is the individual and his or her dignity; c) democracy is understood as a principle that allows for optimization - if the fundamental assumptions of democraticness have been met, a system can still become more democratic and d) a system is more democratic if individuals are able to participate in decision-making outside of elections - public participation therefore has a legitimation function if it is open to all people on equal terms, and if the state maintains its distance from advocates of partial interests (both a de iure and de facto prohibition on joint decision-making).

If we therefore wish to state the hypothesis that public participation in rulemaking enhances the democratic legitimacy of the rules, we must first draw a distinction between ex ante and ex post democratic legitimation. Because ex post legitimation is the providence of sociology and administrative science, the key emphasis in legal studies is on ex ante legitimation. In discussions of whether public participation represents this form of democratic legitimation, it is necessary to carefully delineate the legal-philosophical bases of the concept of democratic legitimation and, at the same time, to avoid the uncritical transfer of solutions between models resting on different bases. The latter can be cited as a fault of that part of Continental law theory that, taking US theory as a model, stresses this function of public participation. Summarizing both models is an exceptionally challenging task in which one must balance the normative and empirical aspects of decision- and lawmaking.

${ }^{92}$ Pfeffer (2006, pp. 237-239). Public participation should therefore not have any additional ex ante legitimation function (so, for example, Schmitt-Glaeser, 1984, p. 49). 
In our case, we may say that public participation serves as a supplement or upgrade to the classical model of democracy or, if you will, to a vertical political system as envisioned by Jellinek, Kelsen, Weber and others, by providing a horizontal model of negotiations and exchanges. In line with the definition of the people as the holder of sovereignty, the main burden of democratic legitimation in modern representative democracies is still borne by the parliament. Affected individuals also appear, on the basis of human dignity and autonomy, as holders of legitimacy, and must therefore be enabled to express their preferences in other, non-electoral, processes. These processes must be designed in such a way that they do not erode the fundamental assumptions of democracy (representation, majority rule) and the state (decision-making autonomy). Under these assumptions, public participation in rulemaking can be understood as a new form of the democratic legitimation of delegated legislation.

\section{References}

Avbelj, M. (2011). Komentar 44. člena Ustave Republike Slovenije. In Šturm, L. (ed.). Komentar Ustave Republike Slovenije: dopolnitev A. Kranj: Fakulteta za državne in evropske študije.

Bogdandy, A. von. (2000). Gubernative Rechtsetzung. Tübingen: Mohr Siebeck.

Bogdandy, A. von. (2001). Demokratisch, demokratischer, am demokratischsten? Zur Steigerungsfähigkeit eines Verfassungsprinzips am Beispiel einer Neugestaltung der Verordnungsgebung. In Bohnert, J., Gramm, Ch., Kindhäuser, U., Lege, J., Rinken, A. and Robbers, G. (eds.). Verfassung, Philosophie, Kirche (Festschrift für Alexander Hollerbach zum 70 Geburtstag), 363-384. Berlin: Duncker \& Humblot.

Brintnall, M. (2011). Public Participation in Rulemaking: Interests v. Information. Available at https://www.researchgate.net/publication/265894346_Public_Participation_in_Rulemaking_Interests_v_Information.

Bröhmer, J. (2004). Transparenz als Verfassungsprinzip: Grundgesetz und Europäische Union. Tübingen: Mohr Siebeck.

Bryde, B. O. (1994). Die Bundesrepublikanische Volksdemokratie als Irrweg der Demokratietheorie. Staats wissenschaften und Staatspraxis, 5(3), 305-330.

Bugarič, B. (2004). Openness and transparency in public administration: challenges for public law. Wisconsin International Law Journal, 22(3), 483-521.

Craig, P. P. (1990). Public law and democracy in the United Kingdom and the United States of America. Oxford: Oxford University Press.

Dworkin, R. (1986). Law's Empire. Belknap Press of Harvard University Press.

Farina, C.R., Newhart, M. and Blake, C.L. (2015). The Problem with Words: Plain Language and Public Participation in Rulemaking. Retrieved March 15, 2016, from http://papers.ssrn.com/sol3/papers.cfm?abstract_id=2564100.

Decision of the German Federal Constitutional Court No. BVerfGE 89, 155.

Decision of the German Federal Constitutional Court No. BVerfGE 93, 37.

Decision of the Supreme Court of the United States of America Immigration and Naturalization Service v. Chadha (1983) 462 US 919. 
Detterbeck, S. (2013). Allgemeines Verwaltungsrecht: mit Verwaltungsprozessrecht. München: C. H. Beck.

Ehlers, D. and Erichsen, H. U. (2010). Allgemeines Verwaltungsrecht (14. Aufl.). Walter de Gruyter.

Fisahn, A. (2002). Demokratie und Öffentlichkeitsbeteiligung. Tübingen: Mohr Siebeck.

Fraenkel-Haeberle. (2013). Die Demokratie "demokratisieren": Experimente der Bürgerbeteiligung in den italienischen Regionalgesetzen. DMS - der moderne staat - Zeitschrift für Public Policy, Recht und Management, 6 (2/2013), 507-522.

Freeman, J. (1997). Collaborative Governance in the Administrative State. UCLA Law Review, 45, 1-98.

Harlow, C. (1999). European Administrative Law and the Global Change. In Craig, P., de Burca, G. (eds.). The Evolution of EU Law, 261-285. Oxford: Oxford University Press.

Hegel, G. W. F. (1821/2005). Grundlinien der Philosophie des Rechts. Akademie-Verlag. Jerovšek, T. and Trpin, G. (2004). Zakon o splošnem upravnem postopku s komentarjem (eds.). Ljubljana: Inštitut za javno upravo pri Pravni fakulteti v Ljubljani.

Johns, M. and Saltane, V. (2016). Citizen Engagement in Rulemaking Evidence on Regulatory Practices in 185 Countries (Policy Research Working Paper 7840). World Bank Group.

Köhler, L. (2017). Die Repräsentation von Non-Voice-Partys in Demokratien: Argumente zur Vertretung der Menschen ohne Stimme als Teil des Volkes. Springer VS.

Kovač, P. and Sever, T. (2014). Participatory administrative procedure: USA vs. selected EU states. In Bohne, E. (ed.). Public administration and the modern state: assessing trends and impact. Basingstoke; New York: Palgrave Macmillan, 144-160.

Koprić, I., Marčetić, G., Musa, A., Đulabić, V. and Lalić Novak, G. (2014). Upravna znanost - Javna uprava u suvremenom europskom kontekstu. Zagreb: Pravni fakultet Sveučilišta u Zagrebu.

Kuhlmann, S. and Wollmann, H. (2014). Introduction to Comparative Public Administration: Administrative Systems and Reforms in Europe. Cheltenham and Northampton, MA, Edward Elgar.

Loughlin, M. (2003). Representation and Constitutional Theory. In Craig, P. (ed.) and Rawlings, R. (ed.). Law and Administration in Europe, 47-66. Oxford: Oxford University Press.

Luhmann, N. (2001). Legitimation durch Verfahren (6. Aufl.). Frankfurt am Main: Suhrkamp.

Mattarella, B. G. (2010). Participation in Rulemaking in Italy. Italian Journal of Public Law, 2, 339-351.

Mendes, J. (2014). Rule of law and participation: A normative analysis of internationalized rulemaking as composite procedures. International Journal of Constitutional Law, 12(2), 370-401.

Meny, Y. and Knapp, A. (1998). A Government and Politics in Western Europe. Oxford University Press.

Möstl, M. (2006). Normative Handlungsformen. In Erichsen, H. U., Ehlers, R. (eds.). Allgemeines Verwaltungsrecht (13. Auflage), 547-600. Berlin: De Gruyter Recht. 
Painter, M. and Peters, B. (2010). Tradition and Public Administration (eds.). Palgrave Macmillan.

Pfeffer, K. (2006). Das Recht auf eine gute Verwaltung. Baden-Baden: Nomos Verlagsgesellschaft.

Pečarič, M. (2017). Can a group of people be smarter than experts? The Theory and Practice of Legislation, 5(1), 5-29.

Petersen, N. (2010). Demokratie und Grundgesetz - Veränderungen des Demokratieprinzips in Art. 20 Abs. 2 GG angesichts der Herausforderungen moderner Staatlichkeit, 58 Jahrbuch des Öffentlichen Rechts 137.

Pollitt, C. and Bouckaert, G. (2011). Public Management Reform: A Comparative Analysis: New Public Management, Governance, and the Neo-Weberian State. Oxford University Press.

Pünder, H. (1995). Exekutive Normsetzung in den Vereinigten Staaten von Amerika und der Bundesrepublik Deutschland. Berlin: Duncker \& Humblot.

Pünder, H. (2009). Democratic Legitimation of Delegated Legislation - A Comparative View On The American, British And German Law. International and Comparative Law Quarterly, 58, 353-378.

Rakar, I. (2014). Sodelovanje javnosti pri pripravi podzakonskih predpisov kot oblika pravnega varstva?. Javna uprava, 50(3/4), 77-86.

Rakar, I. and Tičar, B. (2014). The Rulemaking Procedure - Definition, Concepts and Public Participation. DANUBE: Law and Economics Review, 6(2), 109-119.

Rose-Ackerman, S., Egidy, S. and Fowkes, J. (2015). Due Process of Lawmaking. Cambridge University Press.

Ruffert, M. (2014). The Many Faces of Rulemaking in the EU. Retrieved March 15, 2016, from http://papers.ssrn.com/sol3/papers.cfm?abstract_id=2592092.

Schliesky, U. (2004). Souveränität und Legitimität von Herrschaftsgewalt. Tübingen: Mohr Siebeck.

Schmidt-Assmann, E. (1982). Das allgemeine Verwaltungsrecht als Ordnungsidee und System: insbesondere zur Bedeutung von Rechtsform und Verfahren im Verwaltungsrecht. Heidelberg: Müller, Juristischer Verlag.

Schmidt-Assmann, E. (1991). Verwaltungslegitimation als Rechtsbegriff. Archiv des Öffentliches rechts, 116, 329-390.

Schmidt-Assmann, E. (2006). Das Allgemeine Verwaltungsrecht als Ordnungsidee (Grundlagen und Aufgaben der verwaltungsrechtlichen Systembildung) (2., überarbeitete und erweiterte Auflage). Berlin, Heidelberg: Spinger-Verlag.

Schmitt-Glaeser, W. (1984). Die Position der Bürger als Beteiligte im Entscheidungsverfahren gestaltender Verwaltung. In Lerche, P., Schmitt-Glaeser, W. and Schmidt-Aßmann, E. (eds.). Verfahren als Staats und verwaltungsrechtliche Kategorie. Heidelberg: Heidelberger Forum im Gemeinschaftsverlag R. v. Decker \& C. F. Müller.

Sever, T., Rakar, I. and Kovač, P. (2014). Protecting Human Rights Through Fundamental Principles of Administrative Procedures In Eastern Europe. DANUBE: Law and Economics Review, 5(4), 249-275. 
Teršek, A. (2009). Ustavna demokracija in vladavina prava: ustavnopravni eseji. Koper: FAMNIT - Fakulteta za matematiko, naravoslovje in informacijsko tehnologijo.

Teršek, A. (2014). Teorija legitimnosti in sodobno ustavništvo. Koper: Univerza na Primorskem.

Tischer, J. (2012). Rechtsfragen der Bürgerpartizipation mittels Web 2.0 Anwendungen - das Beispiel Bürgerhaushalt. In Schliesky, U. and Schulz, S. E. (eds.). Transparenz, Partizipation, Kollaboration - Web 2.0 für die öffentliche Verwaltung (Schriften zur Modernisierung von Staat und Verwaltung). Universität Kiel Lorenz-von-Stein-Institut für Verwaltungswissenschaften.

Trips, M. (2006). Das Verfahren der exekutiven Rechtsetzung. Baden-Baden: Nomos Verlagsgesellschaft.

Trute, H. H. (2012). Die demokratische Legitimation der Verwaltung. In Hoffmann-Riem, W., Schmidt-Aßmann, E. and Voßkuhle, A. (eds.). Grundlagen des Verwaltungsrechts (Bd. 1, Methoden, Maßstäbe, Aufgaben, Organisation). München: C. H. Beck, 341-436.

Türk, A. H. (2013). Oversight of Administrative Rulemaking: Judicial Review. European Law Journal, 19(1), 126-142.

Vagt, H. (2006). Rechtsverordnung und Statutory Instrument (Delegierte Rechtsetzung in Deutschland und Grossbritanien). Baden-Baden: Nomos Verlagsgesellschaft.

Virant, G. (2009). Javna uprava. Ljubljana: Fakulteta za upravo.

Vogt, S. and Haas, A. (2015). The future of public participation in Germany: Empirical analysis of administration experts' assessments. Technological Forecasting \& Social Change, 98, 157-173.

Wagner, S. A., Vogt, S. and Kabst, R. (2016). The future of public participation: Empirical analysis from the viewpoint of policy-makers. Technological Forecasting \& Social Change, 106, 65-73.

Woods, N. D. (2015). Regulatory Democracy Reconsidered: The Policy Impact of Public Participation Requirements. Journal of Public Administration Research and Theory, 25(2), 571-596.

Ziamou, T. T. (2001). Rulemaking, Participation and the Limits of Public Law in the USA and Europe. Aldershot: Ashgate. 